\title{
The Relationship of the Aluminium Phosphate Precipita- tion of Organisms of Haemophilus pertussis strains to their other Biological Properties
}

\author{
By J. UNGAR AND P. W. MUGGLETON \\ Glaxo Laboratories Ltd., Research Division, Greenford, Middlesex
}

SUMMARY: Of 46 strains of Haemophilus pertussis, 34 recently isolated strains were all agglutinated by Phase 1 antiserum. Of 12 laboratory strains, 5 had lost their agglutinability. The agglutinable strains were precipitated by aluminium phosphate, and lysed by sodium hydroxide or $10 \%$ sodium desoxycholate and were virulent to mice. The virulent strains, which were precipitable by aluminium phosphate, produced toxic substances in a fluid culture. Precipitation by aluminium phosphate provides a quick method for distinguishing virulent and avirulent strains of $H$. pertussis.

Suspensions of strains of Haemophilus pertussis that are agglutinated by a Phase 1 antiserum have been found also to be completely precipitated with aluminium phosphate, whereas strains that become non-agglutinable by the Phase 1 antiserum also lose this precipitability (Ungar \& Muggleton, 1948). The object of the present communication is to show the relationship between precipitability, agglutinability and certain other biological properties of different strains of $\boldsymbol{H}$. pertussis, either freshly isolated from recent cases of pertussis or maintained in the laboratory for some time.

It has long been known that strains of $H$. pertussis maintained in artificial culture can pass through a series of serologically differentiable phases. In our study no attempt was made to classify the strains used into phases, except that we assigned to Phase 1 all strains that were agglutinated to a high titre (over 1/8000) with a rabbit antiserum prepared by inoculation with a freshly isolated strain.

Altogether we tested 46 strains, of which 34 were received, immediately after isolation, from the Central Public Health Laboratory of the Public Health Laboratory Service or from the North Western Group Laboratory of the L.C.C., and one from Prof. G. A. H. Buttle of the School of Pharmacy, University of London. The remainder were stock strains maintained in this laboratory for various periods; of these, six had been repeatedly subcultured on BordetGengou medium and were no longer agglutinable with the Phase 1 antiserum and the rest had been freeze-dried and stored. All the strains were kept freezedried during the investigation and frequent culture from the freeze-dried state was made to ensure that the strains used in the tests remained constant.

\section{Aluminium phosphate precipitation of the strains}

A standard method of testing the precipitability of the strains was used throughout. The suspensions from $48 \mathrm{hr}$. Bordet-Gengou cultures were washed twice, resuspended in saline containing $0.2 \%$ formaldehyde, to give a concentration of $c .10^{10} \mathrm{organisms} / \mathrm{ml}$, and held at room temperature overnight. 
To $4 \mathrm{ml}$. of suspension in a test-tube $0.3 \mathrm{ml}$. of $5 \% \mathrm{Na}_{2} \mathrm{HPO}_{4}$ was added, followed by $1 \mathrm{ml}$. of $2 \%$ potassium alum, which was added slowly with constant stirring. The mixture was vigorously agitated for two minutes. After standing for $30 \mathrm{~min}$. the floccules had settled out, leaving a water-clear supernatant fluid when precipitation was complete. With strains that were not precipitated the supernatant fluid remained turbid and by comparing it turbidimetrically with a control suspension the percentage of precipitation could be estimated. Precipitation was usually performed at $\mathrm{pH} 6 \cdot 5$. The standardized technique for aluminium phosphate precipitation of the suspensions was devised on the basis of tests in which the concentrations of the phosphate and alum solutions were varied. These tests fixed the minimum amount of adsorbent needed to precipitate all the organisms of a suspension of an average agglutinable strain; for the standard technique double this amount was used. Adsorption of the organisms was found to take place immediately the potassium alum solution was added at room temperature; the two minutes' shaking gave the bacterial cells every chance to come into contact with the phosphate.

\section{The agglutinability of the strains}

The strains were tested for agglutinability by using a twice washed, $0 \cdot 2 \%$ formaldehyde-killed suspension containing $2000 \times 10^{6}$ organisms $/ \mathrm{ml}$. (Brown's opacity tubes manufactured by Burroughs, Wellcome \& Co., London). Equal volumes $(0.5 \mathrm{ml}$.) of serial dilutions of Phase 1 rabbit antiserum and suspensions were mixed in Dreyer's tubes and incubated for $2 \mathrm{hr}$. at $37^{\circ}$ in a water-bath. The same batch of serum was used throughout the tests and the agglutinability of the strain was recorded as the greatest dilution of serum that would just cause granular agglutination visible to the naked eye.

All the 46 strains of $H$. pertussis were tested for precipitability and agglutinability in this way, with results recorded in Table 1.

Table 1. Relationship between agglutinability of Haemophilus pertussis strains with Phase 1 antiserum and precipitability with aluminium phosphate

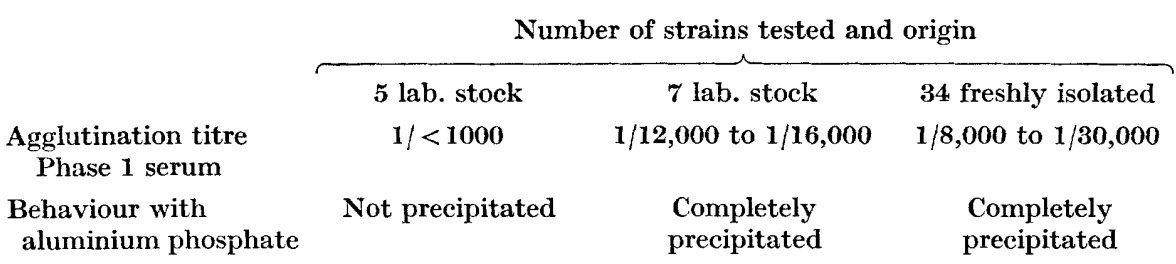

Strains agglutinated by serum dilutions of 1/8000 or more were completely precipitated by the aluminium phosphate. One of the strains (83) grown from the freeze-dried state could be induced to change phase relatively quickly by about six subcultures only, on Bordet-Gengou medium. The strain was tested at each subculture and it was found that agglutinability and precipitability diminished in parallel after the 5th to the 8 th subculture.

Suspensions of $\boldsymbol{H}$. pertussis killed and stored in $0.5 \%$ aqueous phenol lose their agglutinability on storage in the refrigerator (Ungar, 1947). It was found, 
however, that suspensions so treated remained precipitable with aluminium phosphate; this suggests that the loss of agglutinability by spontaneous change of phase on repeated subculture differs in mechanism from that caused by treatment with phenol.

\section{Susceptibility of strains to other precipitants}

Various substances other than alumina and aluminium phosphate precipitate the suspensions. Cadmium phosphate was tested by adding $0.3 \mathrm{ml}$. of $5 \%$ disodium phosphate and $1 \mathrm{ml}$. of $2 \%$ cadmium chloride to $4 \mathrm{ml}$. of suspension. Crystalline magnesium ammonium phosphate was tested by adding $\mathbf{0 . 3} \mathrm{ml}$. of $5 \%$ disodium phosphate and $1 \mathrm{ml}$. of $2 \%$ magnesium phosphate followed by $0.01 \mathrm{ml}$. of ammonia (sp. gr. 0.880 ) to $4 \mathrm{ml}$. of suspension. The percentage of the suspended organisms precipitated by these four adsorbents, using seven strains, and the agglutination titres are tabulated in Table 2.

Table 2. Comparison of agglutinability of seven strains of Haemophilus pertussis with their precipitability by alumina, aluminium phosphate, cadmium phosphate and magnesium ammonium phosphate

$\begin{array}{cccccc}\text { Strain } & \begin{array}{c}\text { Pglutination } \\ \text { titre }\end{array} & \text { Alumina } & \begin{array}{c}\text { Pluminium } \\ \text { phosphate }\end{array} & \begin{array}{c}\text { Cadmium } \\ \text { phosphate }\end{array} & \begin{array}{c}\text { Magnesium } \\ \text { ammonium } \\ \text { phosphate }\end{array} \\ 82 & 1 />\mathbf{1 6 , 0 0 0} & 100 & 100 & 100 & 90 \\ 83 & 1 />16,000 & 100 & 100 & 100 & 90 \\ 104 & 1 />16,000 & 100 & 100 & 100 & 85 \\ 102 & 1 /<500 & 100 & 20 & 10 & 0 \\ 105 & 1 / 1,000 & 80 & 50 & 85 & 75 \\ 167 & 1 /<500 & 80 & 0 & 0 & 0 \\ 154 & 1 /<500 & 90 & 0 & 0 & 0\end{array}$

All four adsorbents behave similarly in that the agglutinable strains are precipitated to a greater extent than the non-agglutinable, the precipitation being complete with each substance except the magnesium salt. It is likely that the mechanism of adsorption is the same for all of them, the degree of adsorption being dependent on the adsorbent used.

Tests on representative strains were designed to elucidate the difference between the two types of organism.

Morphology and staining. Gram- and Giemsa-stained films of the strains used showed that the non-agglutinable organisms were smaller and more coccoid in shape than the agglutinable; they tended to be Gram-positive and also had a slightly greater affinity for basic dyes, which suggested a greater potential acidity in these organisms than in the non-agglutinable. The $\mathrm{pH}$ of suspensions that took up stain in this way was accordingly measured by means of a glass electrode; no appreciable difference in $\mathrm{pH}$ was observed between suspensions of the two types. Measurements of this kind probably give no indication of the potential acidity of the cells, which is what determines their staining affinities. It occurred to us, however, that there might be different $\mathrm{pH}$ 
optima for precipitation of the two types of suspension with aluminium phosphate. We tested the precipitability of suspensions adjusted to various $\mathrm{pH}$ values with hydrochloric acid and sodium hydroxide over the range $4 \cdot 0-8 \cdot 0$. The $\mathrm{pH}$ of the suspension made little difference; non-agglutinable strains were not precipitated over this $\mathrm{pH}$ range, whereas agglutinable strains remained precipitable over the whole of it. Below $\mathrm{pH} 4 \cdot 0$ the aluminium phosphate became increasingly soluble and even agglutinable strains were not precipitated.

The strains were examined at several stages of growth by a modification of Fleming's capsule stain (Jeffrey, 1948), but there was no marked difference between the non-agglutinable and the agglutinable organisms grown for 48 or $72 \mathrm{hr}$. Capsules were demonstrable in both types of organism and varied slightly in depth of staining and thickness according to the age of the culture.

Growth characteristics. It is known that freshly isolated strains will grow only on Bordet-Gengou medium containing about $25 \%$ blood. By repeated subculture we diminished the percentage of blood required to support growth until the strains became non-agglutinable, when they grew sparingly on ordinary digest agar without added blood. In a liquid partly defined culture medium (Cohen \& Wheeler, 1946) the non-agglutinable strains also grew more rapidly, producing a uniform turbidity in the medium, instead of the stringy surface pellicle seen in cultures of freshly isolated, agglutinable strains.

Chemical reactions. During the investigation of the effect of $\mathrm{pH}$ on precipitation with aluminium phosphate, it was observed that the addition of a slight excess of sodium hydroxide solution to a suspension of agglutinable organisms caused a rapid lysis of the bacteria, accompanied by an increase in the viscosity of the fluid. This did not occur with a non-agglutinable suspension, and we therefore investigated the solubility of suspensions of different strains. To $4 \mathrm{ml}$. of a standard suspension containing $20,000 \times 10^{6}$ organisms $/ \mathrm{ml}$. in test-tubes, $1 \mathrm{ml}$. of $\mathrm{N}-\mathrm{NaOH}$ was added. After $30 \mathrm{~min}$. the precipitable organisms were invariably lysed, whereas non-precipitable ones were not. A similar result was obtained with the alkaline $\mathbf{1 0} \%$ sodium desoxycholate solution normally used for investigating the bile solubility of Streptococcus pneumoniae. The solubility of the alum-precipitable strains suggested that this phenomenon might be similar to that encountered in pneumococci, in which a polysaccharide is an essential component of the capsule. Concentrated suspensions of both types of organisms were positive when tested for the presence of polysaccharides by Molisch's reagent.

Suspensions of agglutinable and non-agglutinable organisms were examined electrophoretically after dialysis against a phosphate buffer at pH 6.5; the value of $\mu$ at $4^{\circ}$ for 2 days was $0 \cdot 2$. The organisms in both suspensions migrated towards the anode, indicating that they are negatively charged at this pH, but there was no clear difference between the two types of suspension.

\section{Comparison of agglutinability and precipitability with virulence in mice}

An attempt was made to associate agglutinability and aluminium phosphate precipitability with the virulence of the strains to mice after intranasal instillation (Burnet \& Timmins, 1937). The $48 \mathrm{hr}$. growth on Bordet-Gengou 
medium was scraped off, washed twice in saline and instilled $(0 \cdot 1 \mathrm{ml}$. containing $200 \times 10^{6}$ organisms) into the nostrils of six albino mice (weight 16-18 g.) under ether-chloroform anaesthesia; the strain of animals was descended by close inbreeding from pure-line Strong A 2 ancestors. Virulence was assessed according to the number of mice remaining alive on the 10th day. At the time of infection, organisms from the same cultures were tested for agglutinability, aluminium phosphate precipitability and bile- and soda-solubility. The results summarized in Table 3 indicate a close correlation between precipitability, agglutinability and the bile- and soda-solubility of virulent and avirulent strains and that aluminium phosphate precipitation provides a simple method for distinguishing the two types.

Table 3. Relationship between agglutinability, precipitation with aluminium phosphate, virulence in mice and $\mathrm{NaOH}$ and bile solubility

\begin{tabular}{|c|c|c|c|c|c|}
\hline \multirow{2}{*}{$\begin{array}{c}\text { Strain } \\
\text { no. }\end{array}$} & \multirow{2}{*}{$\begin{array}{l}\text { Agglutination } \\
\text { titre } \\
\text { Phase } 1 \text { serum }\end{array}$} & \multirow{2}{*}{$\underset{\text { precipitation }}{\mathrm{AlPO}_{4}}$} & \multirow{2}{*}{$\begin{array}{l}\text { Virulence in mice. } \\
\text { No. surviving group } \\
\text { after } 10 \text { days }\end{array}$} & \multicolumn{2}{|c|}{ Solubility } \\
\hline & & & & $\mathrm{NaOH}$ & Bile \\
\hline 82 & $1 / \mathbf{1 6}, 000$ & ++ & $1 / 6$ & ++ & ++ \\
\hline 83 & $1 / 16,000$ & $+t$ & $0 / 6$ & ++ & ++ \\
\hline 102 & $1 / 1,000$ & $50 \%$ & $6 / 6$ & 0 & 0 \\
\hline 104 & $1 / 16,000$ & ++ & $0 / 6$ & $+t$ & $+t$ \\
\hline 105 & $1 /<1,000$ & 0 & $3 / 6$ & 0 & 0 \\
\hline 146 & $1 /<1,000$ & 0 & $6 / 6$ & 0 & 0 \\
\hline 154 & $1 /<1,000$ & 0 & $6 / 6$ & 0 & 0 \\
\hline 167 & $1 /<1,000$ & 0 & $6 / 6$ & 0 & 0 \\
\hline 191 & $1 / 20,000$ & ++ & $0 / 6$ & ++ & ++ \\
\hline 192 & $1 / 16,000$ & ++ & $0 / 6$ & ++ & ++ \\
\hline 198 & $1 / 16,000$ & $t+$ & $0 / 6$ & ++ & ++ \\
\hline 199 & $1 / 8,000$ & $+t$ & $2 / 6$ & ++ & ++ \\
\hline 200 & $1 / 12,000$ & ++ & $0 / 6$ & ++ & $t+$ \\
\hline 201 & $1 / 16,000$ & ++ & $0 / 6$ & ++ & ++ \\
\hline 202 & $1 / 8,000$ & ++ & $3 / 6$ & ++ & ++ \\
\hline 203 & $1 / 4,000$ & ++ & $3 / 6$ & ++ & ++ \\
\hline 204 & $1 / 8,000$ & ++ & $0 / 6$ & ++ & $+t$ \\
\hline 205 & $1 / 30,000$ & ++ & $0 / 6$ & ++ & ++ \\
\hline 206 & $1 / 16,000$ & ++ & $0 / 6$ & ++ & ++ \\
\hline ' $N$ ' & $1 / 30,000$ & ++ & $1 / 6$ & ++ & ++ \\
\hline ' $\mathbf{T}$ ' & $1 / 16,000$ & ++ & $0 / 6$ & ++ & ++ \\
\hline ' $\mathrm{O}$ ' & $1 / 4,000$ & $+t$ & $0 / 6$ & ++ & ++ \\
\hline
\end{tabular}

The intracerebral route of infection (Kendrick, Eldering, Dixon \& Misver, 1947) was unsuitable owing to the great differences found between the minimal lethal doses of various strains; moreover only with a few strains have we obtained consistent results by this method.

\section{'Toxin' produced during growth}

We compared the production of toxic substances during growth of the agglutinable and the non-agglutinable strains in theliquid partly defined medium of Cohen \& Wheeler (1946). A number of strains of both types were grown for 12 days at $37^{\circ}$ in $10 \mathrm{oz}$. medical flat bottles containing $100 \mathrm{ml}$. of culture. On 
the 12th day $50 \mathrm{ml}$. quantities of all the cultures were centrifuged for $2 \mathrm{hr}$. at c. 3500 r.p.m., and the supernatant fluids removed. One-fifth ml. of dilutions of $1 / 25$ and $1 / 100$ in saline were injected intradermally into the depilated flank of a rabbit, and the toxic reaction was recorded after $48 \mathrm{hr}$. The centrifuged organisms were resuspended in $0.2 \%$ formol saline and tested for agglutinability. Our results (Table 4) confirmed the observations of Wood (1940), who used serum broth medium and tested the toxicity of the culture fluid by intraperitoneal injection in mice, in that most freshly isolated strains in Phase $\mathbf{1}$ produce a potent 'toxin' during their growth in liquid medium.

Table 4. Relationship between agglutinability and 'toxin' production in liquid semi-defined medium

$\begin{array}{cccc}\text { Strain no. } & \begin{array}{c}\text { Agglutination } \\ \text { titre of organisms }\end{array} & \begin{array}{ccc}\text { Toxic reaction in rabbit skin } \\ \mathbf{1} / \mathbf{2 5} \text { toxin }\end{array} & 1 / 100 \text { toxin } \\ 82 & 1 / 10,000 & ++ & + \\ 102 & 1 / 10,000 & +++ & ++ \\ 104 & 1 / 10,000 & + & + \\ 105^{*} & 1 / 10,000 & +++ & ++ \\ 146 & 1 /<500 & + & 0 \\ 154 & 1 /<500 & 0 & 0 \\ 167 & 1 /<500 & 0 & 0 \\ 191 & 1 /<500 & ++ & + \\ 192 & 1 / 10,000 & ++ & + \\ 196 & 1 / 10,000 & + & + \\ 199 & 1 / 5,000 & + & ++ \\ 203 & 1 / 10,000 & ++ & + \\ 204 & 1 / 10,000 & + & ++ \\ 209 & 1 / 5,000 & ++ & + \\ 210 & 1 / 10,000 & + & +\end{array}$

$++=$ Dermonecrotic reaction and haemorrhage $c .4 \mathrm{~cm}$. diameter.

$++=$ Dermonecrotic reaction and haemorrhage $c .2 \mathrm{~cm}$. diameter.

$+\quad=$ Dermonecrotic reaction without haemorrhage $c .1 \mathrm{~cm}$. diameter.

$0 \quad=$ No reaction.

* Strain 105 is exceptional in that, besides forming a toxic substance, it is partly virulent in mice (see Table 3).

The non-agglutinable strains, with the exception of strain 105, did not produce a potent toxin. An investigation of the toxins produced by some of the Phase 1 strains confirmed Wood's observations that the culture fluids are detoxified by Seitz filtration, and by treatment with $\mathbf{0 . 2} \%$ formaldehyde for two days, and by mild heat. We found further that the toxic solution was detoxified on passing through a diatomaceous earth candle or a sterilizing (No.5) sintered glass filter, as well as by prolonged high-speed centrifugation (with precautions against a rise in temperature). The toxic antigenic component can also be precipitated with aluminium phosphate in the same way as a bacterial suspension (Ungar \& Muggleton, 1948). These observations lead us to the conclusion that the toxin is probably a suspension of very fine particles rather than a true solution and is the result of disintegration of dead bacterial cells during growth of the culture. This may be related to the fact that the non-agglutinable strains, which do not 
produce a toxic culture fluid, may be more resistant to disintegration, just as they are more resistant to the action of sodium hydroxide and bile salts. Alternatively the change of phase may be accompanied by cessation of toxin production. Table 5 summarizes the differences between the two types of strain.

Table 5. Summary of differences between strains of Haemophilus pertussis

\begin{tabular}{|c|c|c|}
\hline Property & $\begin{array}{l}\text { Agglutinable strain } \\
\text { (Titre } 1 />8000 \text { with } \\
\text { Phase } 1 \text { serum) }\end{array}$ & $\begin{array}{c}\text { Non-agglutinable strain } \\
\text { (Titre } 1 /<500 \text { with } \\
\text { Phase } 1 \text { serum) }\end{array}$ \\
\hline $\begin{array}{l}\text { Precipitation with aluminium } \\
\text { phosphate }\end{array}$ & Complete precipitation & No precipitation \\
\hline Morphology & $\begin{array}{l}\text { Short Gram-positive bacil- } \\
\text { lus, about } 1 \cdot 5 \mu\end{array}$ & $\begin{array}{l}\text { Shorter and smaller than ag- } \\
\text { glutinable organisms, about } \\
1 \mu \text {, and tends occasionally } \\
\text { to be Gram-positive }\end{array}$ \\
\hline Capsulation & $\begin{array}{c}\text { Capsulated (wide zone } \\
\text { noticed after } 24 \mathrm{hr} \text {.) }\end{array}$ & Capsulated \\
\hline $\begin{array}{l}\text { Solubility in } \mathrm{NaOH} \text { and bile } \\
\text { salt }\end{array}$ & Completely soluble & Insoluble \\
\hline Virulence in mice & Mostly virulent & Avirulent \\
\hline $\begin{array}{l}\text { Endotoxin production in } \\
\text { liquid medium }\end{array}$ & Mostly toxin producing & Non-toxic \\
\hline
\end{tabular}

\section{DISCUSSION}

After isolation from the human host, strains of Haemophilus pertussis undergo changes of phase on repeated subcultivation and lose their ability to be agglutinated by Phase 1 antiserum. Accompanying this loss of agglutinability is some change that makes the cell less susceptible to adsorption by aluminium phosphate and consequently less precipitable. The means by which bacterial cells are adsorbed on such insoluble compounds is not properly understood. It is possibly due to differences in charge on cells and adsorbent, but if this be so, the process is strangely unaffected by change of $\mathrm{pH}$. Cells that have lost their agglutinability by Phase 1 antiserum and are no longer susceptible to the dissolving action of sodium hydroxide or bile salt still have capsules demonstrable in stained preparations. This suggests a condition similar to that encountered in the streptococcus group, in which the bile solubility of Streptococcus pneumoniae is associated with an antigenically active polysaccharide capsule. The fact that the loss of agglutinability with Phase 1 serum shows fairly close correlation with the loss of virulence to mice infected by the intranasal route, and the absence of endotoxin when grown in simplified media, are noteworthy. The changes that take place on repeated subculture, resulting in a much more rapid growth and simpler growth requirements, are certainly accompanied by a 'deterioration' of the strains. It is well known that among some of the pathogenic bacteria the prevalence of rough dissociants of laboratory strains is accompanied by loss of virulence and toxigenicity, and this also seems to occur with Haemophilus pertussis strains. 
Our thanks are due to Dr R. Cruickshank, Director of the Public Health Laboratory Service, Central Public Health Laboratory, for the supply of freshly isolated pertussis strains; to Professor G. A. H. Buttle of the School of Pharmacy, University of London, for the supply of pertussis strains; and to Mr E. G. Tomich and Miss A. A. Free, of Glaxo Laboratories, Research Division, for the electrophoretic examinations.

\section{REFERENCES}

Burnet, F. M. \& Trmmins, C. (1937). Experimental infection with Haemophilus pertussis in the mouse by intranasal inoculation. Brit. J. exp. Path. 18, 83.

Cohen, S. M. \& Wheeler, N. W. (1946). Pertussis vaccine prepared with phase 1 cultures grown in fluid medium. Amer. J. publ. Hlth, 36, 371.

JEFFERY, T. H. (1948). Method of demonstrating capsules. Modification of Fleming's nigrosin stain. Bull. Inst. med. Lab. Techn. 14, no. 36, 3.

Kendrick, P. L., Eldering, G., Dixon, M. K. \& Misver, J. (1947). Mouse protection tests in the study of pertussis vaccines. Amer. J. publ. Hlth., 37, 803.

Ungar, J. (1947). Reports IVth International Congress of Microbiology, Copenhagen.

Ungar, J. \& Muggleton, P. W. (1948). Aluminium phosphate as precipitant of agglutinable and non-agglutinable strains of $H$. pertussis. Nature, Lond., 162, 734.

Ungar, J. \& Muggleton, P. W. (1949). The precipitability of Haemophilus pertussis strains with aluminium phosphate and its significance. J. gen. Microbiol. 3, Proc. ii.

Wood, M. L. (1940). A filtrable toxic substance in broth cultures of $B$. pertussis. J. Immunol. 39, 25. 